\title{
Emergence of a sustainable business community*
}

\author{
Joseph Fiksel \\ Life Cycle Management, Battelle Memorial Institute, 505 King Ave., Columbus, \\ Ohio 43221, USA
}

\begin{abstract}
Global population and environmental pressures are challenging multinational companies to develop new business strategies founded upon the principles of sustainabilityassuring that they can meet the needs of both present and future generations of customers and stakeholders. Corporate sustainability requires understanding the "triple bottom line", which includes economic, societal, and ecological performance. It involves designing products and processes with a full awareness of their life-cycle costs and benefits, and seeking new technologies to create more value with fewer resources. To put sustainability into practice, companies are beginning to transform their core business processes and develop environmentally and socially responsible products and services. Many are adopting the concepts of industrial ecology and green chemistry in an effort to transform their operations from a linear to a closed-loop business model. This changing climate is creating new opportunities for breakthrough research and development, ranging from nanotechnology to green chemistry.
\end{abstract}

\section{BUSINESS PERSPECTIVE ON SUSTAINABLE DEVELOPMENT}

The underlying principle of sustainable development (SD) was first articulated by the Bruntland Commission in 1987, which defined SD as industrial progress that meets the needs of the present without compromising the ability of future generations to meet their own needs [1]. Subsequent interpretation of this principle from a business perspective has led to the adoption of a "triple bottom line" framework, comprising the following dimensions:

- $\quad$ economic prosperity and continuity for the business and its stakeholders

- $\quad$ social well-being and equity for both employees and affected communities

- $\quad$ environmental protection and resource conservation, both local and global

Thus, SD has become an extremely broad concept that encompasses a variety of critical issues related to human and ecological welfare, including climate change mitigation, natural resource conservation, poverty reduction, and protection of human rights. It transcends and subsumes earlier industry practices, such as pollution prevention and design for environment, by combining environmental stewardship with social responsibility and wealth creation.

Confronted by rising stakeholder concerns over SD issues, the business community has begun to recognize that long-term success depends not only on financial performance, but also on social and environmental performance. In effect, corporate sustainability is a natural consequence of a corporation's commitment to address the needs of both customers and other stakeholders, including employees, local communities, regulators, investors, lenders, business partners, and nongovernmental organizations (NGOs). Growing public awareness of SD has created opportunities for companies to address

\footnotetext{
*Lecture presented at the IUPAC CHEMRAWN XIV Conference on Green Chemistry: Toward Environmentally Benign Processes and Products, Boulder, Colorado, USA, 9-13 June 2001. Other presentations are published in this issue, pp. 1229-1330.
} 
changing stakeholder expectations with new technologies, products, and services, thus gaining competitive advantage.

The rising awareness of SD among businesses is due in large part to the efforts of the World Business Council for Sustainable Development (WBCSD), a Geneva-based consortium of over 100 leading companies formed in 1990, whose publications have helped to demonstrate the business value of sustainability [2]. Important drivers for business adoption of SD include [3]:

- $\quad$ evidence that companies can create shareholder value by adopting "eco-efficient" production methods to improve both operating efficiency and market positioning

- $\quad$ increasing acceptance among top executives of the ethical obligations associated with "corporate citizenship"

- $\quad$ emergence of doctrines such as "extended producer responsibility", which broaden corporate accountability and raise public expectations regarding company behavior

- $\quad$ explosive growth of electronic communication, creating global accountability and transparency for companies that do business in developing nations

- recognition by the financial community that sustainably managed companies tend to generate superior economic returns

- $\quad$ increasing efforts in constructive engagement and dialogue with external stakeholders

\section{LESSONS FROM THE LEADING EDGE}

In recent years, a number of pioneering multinational corporations have established highly visible sustainability programs. For example, top management at BP Amoco, Dow, DuPont, Ford, General Motors, Royal Dutch Shell, and IBM have gone public with ambitious commitments to generate shareholder returns while addressing the needs of humanity. In general, the common purpose of these programs is to shift the company operations from a traditional, resource-intensive, and profit-maximizing business model to a more eco-efficient, socially responsible, and value-maximizing model. This shift aligns nicely with the financial goal of increasing shareholder value by raising profits while reducing the cost of capital, i.e., doing more with less.

Early adopters of SD have included companies in many different industries, such as chemicals, consumer products, pharmaceuticals, motor vehicles, computers and electronics, forest products, petroleum, and even floor-coverings. Rather than following a prescribed approach, each company has explored how it can integrate sustainability into its own business strategy. Typically, there are several levels of sustainable business practices, with increasing levels of difficulty. The most basic level is corporate initiatives such as philanthropic programs aimed at solving sustainability problems. The next level often involves reducing the "ecological footprint" associated with the product life cycle, including manufacturing, use, and end-of-life disposition. The most challenging level is enhancing the inherent social value created by the firm's operations, products and services, which may range from assuring human health and nutrition to stimulating consumer education and growth of new businesses.

Companies that are successful SD practitioners typically view SD as a strategic issue, have the chief executive officer or other senior executives as champions, and encourage cross-functional collaboration throughout the organization in pursuit of innovative products and business models. Moreover, for SD to become truly integrated into business decisions, a systematic SD performance measurement process is essential [4]. Sustainable businesses need to systematically consider the impacts associated with each stage in the product life cycle, including resource extraction, procurement, transportation, manufacturing, product use, service, and disposition. Most companies that are committed to SD have established measurable performance goals and have expanded their annual environmental, health and safety progress reports into sustainability reports aimed at stakeholder communication. For example, DuPont has adopted a company-wide sustainability indicator (shareholder value added per pound of product) that reflects their overall goal of creating greater value with 
fewer resources. Tools such as life-cycle assessment are increasingly used to measure performance in terms of total societal impacts. Meanwhile, emerging consensus standards such as the Global Reporting Initiative [5] are helping to establish key performance indicators that will support industry benchmarking.

Much of Battelle's sustainability consulting work has focused upon how businesses can generate shareholder value and strategic value by creating societal value. The ValuWeb ${ }^{\mathrm{TM}}$ methodology has been applied in many different contexts to provide explicit linkages, including both direct and indirect pathways, between specific product or process improvements and ultimate value creation for stakeholders. One example is the transformation of Ford Motor Company's historic Rouge Plant, in Dearborn, Michigan into a sustainable automotive manufacturing center. By investing in a state-of-the-art workplace with an ecologically harmonious architectural design, the company expects to improve employee morale, loyalty, health, safety, and productivity, thus contributing significantly to both the bottom line and the corporate image. Another example is a $\$ 3.5$ million project that Battelle is conducting on behalf of the global cement industry, sponsored by the WBCSD. This study is developing a 20-year road map toward a sustainable cement industry, ranging from stakeholder engagement to sustainable technology innovations.

\section{INDUSTRIAL ECOLOGY AND GREEN CHEMISTRY}

Many of the sustainable business pioneers discussed above have adopted industrial ecology (IE) as a broad, holistic framework for guiding the transformation of industrial systems from a linear model to a closed-loop model that resembles the cyclical flows of ecosystems [6]. IE seeks to emulate a fundamental characteristic of natural systems - there is no waste, since one creature's waste becomes another creature's food. Thus, IE provides a foundation for rethinking conventional product or process technologies and discovering innovative pathways for re-use and recovery of industrial waste streams. Many companies have made efforts to systematize IE principles in the form of design guidelines. For example, 3M, Caterpillar, AT\&T, Johnson and Johnson, and Bristol-Myers Squibb have developed Product Life Cycle Management programs that include Design for Environment (DfE) or Design for Sustainability guidelines.

Green chemistry is a particular branch of DfE that is concerned with environmentally benign chemical synthesis and processing. It differs from conventional DfE efforts in that DfE tends to focus on the mechanical design of products or packaging, resulting in incremental improvements for discrete products (e.g., an inkjet printer or a bottle of shampoo). In contrast, green chemistry focuses on fundamental breakthroughs in product or process chemistry, deals with properties of materials at the molecular level, and, therefore, has the potential to discover more radical and more powerful solutions with greater beneficial impacts. Green chemistry research has focused on areas such as:

- increasing the eco-efficiency of industrial processes through enhanced separation and extraction methods, alternative chemistries, or novel catalysis methods

- developing new, more sustainable products through use of renewable resources, biodegradable materials, or regeneration of feedstocks from waste by-products

Researchers at Battelle Memorial Institute have been using green chemistry to develop economically attractive polymer products based on renewable feedstocks, for example:

- an environmentally compatible, soy-based plasticizer for use in the processing of polyvinyl chloride resin

- a soy-based wood adhesive that performs better than current adhesives, is less costly, and will reduce emissions of volatile organic compounds

- a novel, readily de-inkable toner technology based on soy resins, addressing a growing need in the manufacture of secondary fiber from office waste 
- $\quad$ lactide polymer production from fermentation processes, for use in manufacture of biodegradable polymers

- $\quad$ a cost-effective "green" solvent, consisting of a water-based, biodegradable micro-emulsion, that uses the excellent solvent characteristics of methyl ester of soybean oil

These are but a few examples of recent innovations motivated by sustainability considerations.

\section{CONCLUSIONS}

The emergence of sustainable development as a strategic force within the business community has created new opportunities for companies to fundamentally change how they design products, engage suppliers, operate facilities, and service customers. Sustainability awareness is spurring breakthrough innovation that will introduce "discontinuities" based on new technologies, such as fuel cells, "smart" materials, bio-based processing, and nanotechnology. It is quite plausible that those companies who fail to understand the sustainability drivers may find themselves displaced by the entry of new, more agile competitors [7]. Ironically, a few well-established companies have delayed adoption of sustainability because they perceive it as a threat analogous to the introduction of more stringent environmental regulations, and are adopting a conservative "wait and see" attitude. The real threat may come not from regulatory agencies, but from competitive challenges in the marketplace, and those who delay may not have time to recover.

\section{REFERENCES}

1. World Commission on Environment and Development. Our Common Future, Oxford University Press, New York (1987).

2. S. Schmidheiny with the Business Council on Sustainable Development. Changing Course: A Global Business Perspective on Development and the Environment, MIT Press, Cambridge, MA (1992).

3. J. Fiksel and D. G. Fiksel. "From Here to Sustainability: A Global Perspective on Sustainable Development", Chemistry Business April 2001.

4. J. Fiksel. "Measuring Sustainability in Eco-Design". In M. Charter and U. Tischner (Eds.). Sustainable Solutions: Developing Products and Services for the Future, Greenleaf Publishing, Surrey, UK (2000).

5. Global Reporting Initiative. Sustainability Reporting Guidelines on Economic, Environmental, and Social Performance, Boston, June 2000.

6. E. Lowe. "Industrial Ecology: A Context for Design and Decision". In Design for Environment: Creating Eco-Efficient Products and Processes, J. Fiksel (Ed.), McGraw-Hill, New York (1996).

7. S. L. Hart and M. B. Milstein. "Global Sustainability and the Creative Destruction of Industries", Sloan Management Review Fall 1999. 